\title{
Education on the rails: a textual ethnography of university advertising in mobile contexts
}

\author{
Colin Symes and Christopher Drew \\ Corresponding author: Colin Symes, \\ Department of Education, \\ Macquarie University, \\ Sydney, New South Wales \\ Australia 2109. \\ Colin.Symes@mq.edu.au \\ Christopher Drew, \\ School of Social Sciences, Business \& Law, \\ Teesside University, \\ Middlesbrough, Tees Valley \\ United Kingdom TS1 3BX.
}

\begin{abstract}
As universities have succumbed to market discourses, they have adopted advertising strategies. It is not uncommon to see advertisements for them displayed in such mobile spaces as railway stations and alongside highways. Whilst it is true that such environments have always sought to take advantage of populations in transit, the fact that higher education institutions have turned to them as promotional sites, reflects the fact that the 'transit' demographic now includes large numbers of young people and high school students. In this paper, a sample of higher education advertisements found in Sydney's transit spaces is analysed along with the 'rationale' provided by advertising companies responsible for their design. It is argued their existence reflects the fact that universities compete against one another for students and need to develop a persuasive 'brand'. Thus in line with neo-liberalist constructions of subjectivity, they individualise the educational experience, and translate that experience into an economic asset, as a value-adding process. It is of note then that much of the imagery and copy of the advertising 'visualises' education as a journey and underpins the fact that mobility is an inescapable predicate of quotidian life.
\end{abstract}

Keywords: higher education, neo-liberalism, advertising, mobility, subjectivity, Bradley Report 
"The main objective is to keep the student shoppers rolling in, coming through the doors."

(Hil 2012: 46)

In the large corpus of literature on mobility, one area that has received scant attention is the flow of information, symbols and images through transit spaces. Much of this flow, in the form of signage, relates to 'overseeing' the movement of passengers onto and off transport. Yet there is a considerable amount of transit signage that is not concerned with choreographing and staging mobility (Jensen 2015). Its presence stems from the recognition that venues of mobility such as railway stations are propitious sites for advertising, not least of all due to the regular funnelling of potential consumers through their spaces. For stations have been 'commercialised' in every sense of the word. As well as being sites of retail activity (Jensen 2014: 148; Ross 2000: 240), they are also sites where advertisements, for a range of commodities and services, including this paper's concern, higher education, are displayed (Hil 2012: 53). Nor is this peculiar just to railway stations. Advertising is also found alongside highways, and on the sides and back of buses and trucks, thereby adding textual dimensions to the motorised experience (Edensor 2003; Gudis 2004).

The decision on the part of universities and other tertiary institutions to advertise in transit spaces, which is relatively new, is emblematic of the plight of Australia's higher education, of the fact that in the last two decades or so, its provision has undergone major reform. Universities now operate more like corporations, and are exposed more than ever to neoliberal imperatives in which the onus is on the individual to 'identify' a service that is commensurate with their ambitions and aspirations (Miller and Rose 1997). It is a paradigm that casts students as agentive consumers who vote with their 'seats', and universities as institutions that solicit students in an increasingly crowded marketplace of private and public providers. Although the former only cater for $5 \%$ of the students enrolled in Australia's higher education system (Moodie 2011: 63), the 'for profit' private colleges are high profile advertisers. Advertisements, now augmented by social media and other forms of electronic promotion, continue to provide illustrations of how higher education institutions 'picture' themselves to prospective students. Yet though there is now much analysis examining the impact of markets on the provision of higher education, particularly its public forms, very little of that analysis examines university advertising. One might expect that such advertising would highlight the differences between higher education institutions. Yet those directed at Sydney's mobile community, the main subjects of this paper's analysis, are markedly similar in championing universities as places where instrumentalism rules, where knowledge 
acquisition is tethered to career acquisition. In clear recognition that universities dispense “positional goods" that ameliorate career opportunities (Marginson 1997a: 44), advertisements by and large marshal the idea that educational movement, through the attainment of value-adding credentials, is a predicate of social advancement. Indeed, there is now sociological evidence indicating that limited access to such public goods as education exacerbates disadvantage, and that capacity for actual mobility helps propel social mobility (Kaufmann 2002: 12, 30; Urry 2000a: 2). The preparedness to travel plus the means to travel, both locally and for many, internationally, are significant factors in accessing educational goods, especially at their highest levels.

Educational immobility in effect translates to social immobility. This is reflected in the pejorative overtones associated with being sessile, of being stationary, and which are further reflected in the exhortations of 'getting a move on', 'hurrying up'. Further, think of how being slow, of taking time, is disparaged, particularly in education, where alacrity is esteemed, pedestrianism disparaged. Indeed, university advertisers are adroit at giving articulate expression to the educational values adhering to these sedentary and nomadic polarities (Jensen 2009: 141). Central to their rhetorical manoeuvres is the nexus between space and time forged through mobility: that universities (like schools) are stationary institutions through which individuals move, over specified periods of time, all the while conferring value on their attainments; that is, if they are prepared to undertake the selfproduction involved. Advertisers, as is argued in this paper, invariably project the promise of social and economic advancement through the transporting experiences of higher education, though more to the point is that they give iconographic expression to the differentiated import of the pre-graduation experience, that attendance at university $\mathrm{X}$ rather than $\mathrm{Y}$ will enhance a student's capacity to compete in labour and education markets. The sense of mobility that is visualized then, is invariably a multi-valent one, invoking not just the aforementioned metaphorical senses of being mobile but also literally mobile, as in travelling to new places as result of education or using transport to access educational institutions.

Specifically, advertisements in transport contexts take advantage of the fact that their addressees are actually on the move. Further, they encourage them to see study as a form of journeying, as one affording the opportunity to move forward, as a mode of getting places. They provide a synergy between mobility in the material and rhetorical sense. In exploring this synergy in higher education advertising, the paper employs 'textual ethnography', a method of analysis that attempts to understand signs in their habitats and contexts. In this instance, this is defined as everything from the policy environment of which university 
advertisements are iconographical embodiments to the spaces in which mobile communities apprehend them. The particular focus of this paper's analysis is a selection of the approximately fifty or so higher education advertisements, some from private colleges, that were observed (and photographed) in and around railway stations and on trains in Sydney, throughout 2015 and early 2016. It is of note that the advertising was not by any means restricted to the promotion of institutions located in Sydney, for advertisements on behalf of a small number of regional and inter-state universities were also sighted.

\section{The "iconomy" and higher education}

Those images, logos, symbols, buildings, advertisements and websites that are designed to excite desires, wants and economic activity, form what Terry Smith (2006: 2-3) has called the "iconomy". Although his analysis is primarily with its global manifestations, there are also local iconomies, of more limited reach, scale and range. They now encompass institutions, many of them public, formerly spared 'iconomic' imperatives, but which under the neoliberal discourses Australian governments now espouse, have been obliged to adopt. Universities are no exception. They have long since succumbed to pressure to 'iconomise' and now, through the cultivation of brand identities, routinely advertise for custom. This development is commensurate with other reforms, also inspired by neo-liberalism, that have forced universities to operate more like corporations. Exposure to market forces was designed to reduce their dependence on government subvention, and which the granting of powers to sell courses to international students were also intended to engender. When these trends first appeared in the 1980s, through reforms initiated by the Hawke government, they were accompanied by the recognition of the impact of globalisation on Australia's economy and the corresponding need to raise the quality of its 'human capital' through increasing university participation (Dawkins 1988: 31). The neoliberal shift in higher education policy also spelt, with the introduction of a Higher Education Contribution Scheme (HECS), the end of 'free' higher education. On the broader front, such developments served to 'normalise' the privatisation of public goods in general, and steer Australia away from post-war Keynesianism. It was but one element of a culture in which 'private', in line with other neoliberalist precepts such as deregulation, accountability and competition, was gauged preferable to 'public' (Bauman 1988). By regularly commissioning inquiries into higher education, governments cajoled universities into reordering their educational priorities, aligning them to Australia's economic goals.

Though on paper the Dawkins' reforms inspiring these changes were intended to 
promote a unified national system of higher education, in reality they did anything but. For one of the more far-reaching of the reforms, was that of conferring university status on the nation's Colleges of Advanced Education (CAEs), which had been instituted to cater for students whose intellectual proclivities were more oriented towards application than knowledge development. ${ }^{1}$ However by the 1970s CAEs had begun to confer degrees and undertake research, and were increasingly operating like real universities, albeit ones with strong, as befitted their provenance, vocational profiles (Davies 1989: 65; Gallagher 1982: 23). Indeed, the unification prompted unofficial stratification as the elite, middle rung and the newly consecrated institutions sought to establish distinctive semiotic 'identities' (Marginson 1997: 251; Symes 1996: 137-8). It prompted a rear guard action on the part of the 'real' universities, as opposed to the 'newbees', to defend themselves as places of 'free enquiry', that were committed to protecting the societies they served from moral and epistemological fraud, from false idols and ephemeral values (Davies 1989: 96). ${ }^{2}$ This was new, for hitherto as hermetic institutions insulated from 'real world' imperatives, universities were not impelled to cultivate semiotic identities, or if they did, it was confined to their letterheads (Temple 2006: 15), or in their advertising for new staff.

In the three decades or so since Dawkins' reforms, the application of market principles to the nation's higher education sector has markedly increased. It reached a new apogee in 2009 when the Rudd/Gillard Labor government implemented one of the recommendations from the Bradley review (Review of Higher Education 2008: 152): lifting the ceiling on Commonwealth Assisted Places (CAPs). The abandonment of numerus clausus ('closed number'), the traditional mechanism for restricting and regulating student enrolments (Bourdieu 1988: 161), allowed universities to admit as many students as they could reasonably accommodate without compromising their education standards or overburdening their facilities. Importantly, Commonwealth money would follow the students. In effect, the meritocratic calculus underpinning the Australian Tertiary Admissions Rankings (ATAR) was abandoned and universities were given carte blanche to set their own entry standards (Review of Higher Education 2008: 157). Even though ATAR rankings continued to "operate as proxies for educational quality" (James et al 1999: 75; Marginson

\footnotetext{
${ }^{1}$ The Martin Report, which was responsible for the creation of the College of Advanced Education, makes this distinction (First Report of the Commonwealth Advisory Committee on Advanced Education 1966: 23).

${ }^{2}$ The Murray Report promoted this view, and argued that "high intellectual ability" was scarce in Australia, something its universities needed to redress (Report of the Committee on Australia universities 1957: 8).
} 
2007: 44), the number of places offered to students with ATARs below 60 rose by 85 percent between 2009 and 2016 (Bagshaw 2016: 27; Norton 2013). ${ }^{3}$ With it, the responsibility for maintaining academic standards shifted from universities to the Tertiary Education Quality and Standards Agency (TEQSA). At Bradley's urging, this audit unit was established to ensure that the clamour to satisfy student demand did not corrupt academic standards. In this context, the matter of who should proceed to higher education was less dependent on a measure of student capacity, and more a "decision that only the prospective student can make with information about his or her alternative options" (Kemp and Norton 2013: 3). In order to remain relevant and sustain a healthy bottom line in this increasingly crowded tertiary marketplace, institutions were impelled to ensure that the increasingly valuable students would keep "coming through the doors."

We now turn to the 'iconomic' results of these policy shifts.

\section{Outdoor education}

One is that it has become incumbent on tertiary institutions to disseminate information about the distinctiveness of their 'product' and its applicability to the lives and futures of potential students. Hence, the intensification of advertising campaigns to enhance brand diffusion, along with an expansion of the budgets of university marketing departments to boost their institution's iconomy, this at a same time when support for teaching was cut, ostensibly because of budget constraints (Klopper and Power, 2014). ${ }^{4}$ One such marketing department, that of the then University of Western Sydney (UWS), was handed \$20 million dollars in 2015 to oversee a re-branding exercise, involving the development of a new name for the institution and logo along with an extensive advertising campaign to promulgate these 'iconomic' changes. This enabled much of the semiotic work involved to be outsourced to leading advertising agencies and for the results to be positioned across Sydney's linguistic and semiotic landscape (Jaworski and Thurlow 2010; Metro-Rolland 2011), specifically in

\footnotetext{
${ }^{3}$ The "Group of Eight" universities in the interests of protecting their cohorts of able students, have generally maintained high ATAR scores (Nelson 2013). In an attempt to staunch the flow of poor quality students into their undergraduate programmes, they have proposed an ATAR floor (Mather 2013). That is not to say an inflated ATAR predicts academic success: many students with low ATARs prove the contrary, and vice versa.

${ }^{4}$ Between 1996 and 2011, casuals increased 81\% compared to just 37\% for permanents over the same period (Kimber and Ehrich 2015). At the same time, professional development and continuity has suffered as sessional teachers juggle their loads with off-campus employment, worry about job insecurity, all of which serves to reduce commitment to student learning that, ironically, many universities upsell in their advertising (Klopper and Power, 2014).
} 
such transit sites as railway stations. The resultant advertisements were designed to give the new name (Western Sydney University (WSU)), literally, "various faces", many of them visualising WSU's diversity and "unlimited" potential. They helped broadcast the news of the 'new' institution along Sydney's transit corridors.

WSU is not alone in employing advertising in its quest to gain positional advantage in the higher education sector. However, the magnitude of its outlay is considerably larger than that of its rivals (Cervini 2015). This seems unwarranted, especially as the correlation between investment in marketing and increased enrolments is undemonstrated (Favaloro 2015: 496; Thornton and Shannon 2014: 165). Further, research examining the power of advertising on university choice, suggests advertising has very little impact when compared with word of mouth, careers advisors and the 'open day' experience, when prospective students acquire a visceral feel for a 'uni' and experience its bricks and mortar (board) glories (James et al 1999: 15).

Among the agencies used for higher education marketing are APN Outdoor Group Limited, which specialises in alfresco advertising, especially that in transit spaces, in billboards adjacent to railway lines and highways, in station precincts, on buses and trains. As one might expect, APN makes enormous claims about the efficacy of its advertising, that billboards cannot be switched off, that advertisements on moving vehicles have the capacity to reach remote corners of the city, that those in stations have a "captive commuter audience" and so on. Of particular salience though, since it is higher education's target demographic, such advertising is especially good at reaching the "Gen Y" 5 and "CBD [Central Business District] workers", who, are "notoriously difficult to reach through normal channels". Apparently, while waiting on platforms, as much as twelve-minutes per trip according to APN, they will alternate between looking online and looking at station advertising. ${ }^{6}$ Further, in order to arouse and maintain the attention of commuters, there is a high turnover of station advertisements on both print and digitized billboards, the latter of which APN sells on a timeshare and rotation basis. These allow advertisers to purchase timeslots during peak and weekend hours. For example, higher education advertising is seasonal, occurs mostly during the spring and summer months, when universities hold open days and matriculating students are deliberating on their education futures. Moreover, such advertising is designed to be seen

\footnotetext{
${ }^{5}$ Generation Y, also known as the millennials, fit a typical target core clientele for universities, being the age group on the cusp of their working lives and often seeking a career boost through tertiary education.

${ }^{6}$ http://www.apnoutdoor.com.au
} 
by the large demographic of prospective undergraduate students, who, as a direct result of NSW government's decision to de-zone its secondary schools (Symes 2007), now travel to and from schools on trains. Moreover, they are designed to be read in preference to the advertisements adjacent to them, which advertise such 'millennial' essentials as phone plans, gap years, cheap textbooks and so on.

Should an advertisement engage a prospective student there is an assumption that they will take the opportunity to go on-line and learn more about that being promoted. Invariably including a URL for this purpose, the "narrative architecture" (Genette 1997) of the contemporary advertisement is not designed to be fully autonomous; rather, as APN suggests, it is designed in such a way as to 'drive' the 'connected consumer' to another site, and then, possibly, onto another one and another, ad nauseam. Hence, advertisements, with a dearth of fine print, are brief and to the point, allowing their 'stories' to be narrated or explained elsewhere - as in an infinite regress of endnotes. In short, most higher education advertising functions as a frontispiece, as a catalytic discourse that engages with another series of texts, mostly on line, which embed the advertising (Thornton and Shannon 2014: 164). Indeed, many university advertisements, particularly those headlining stories of successful graduates, invite their readers to go online if they wish to learn more about how a university helped student $X$ to realise their educational dreams (Heywood at al 2011: 184).

\section{Picturing the future, picturing the past}

This is the case in the "Transform Your Future" series of advertisements commissioned by the University of New South Wales (UNSW), many of which were mounted in Sydney's transport spaces. Higher education advertising campaigns such as this one often come in series, presumably to defray any inference that the stories they narrate are rare ones. The example illustrated in Figure 1 is one of three advertisements in the UNSW "Transform Your Future" series, sharing similar themes, taglines, catch phrases, structural, typographical and chromatic properties. They are also found in other series of advertisements originating from the same institution, and which assist to enhance the distinctiveness of the UNSW iconomy in Sydney's linguistic landscape. They include UNSW's escutcheon, which is unusual, since most universities have long since abandoned their use, adopting logos instead — semiotic emblems of their corporatisation. They also have a right-hand panel, with a yellow background, UNSW's livery, and where the addressee is invited to "Discover Lily's story". She was someone who happened to "ask why not" and as a result "great things" happened to her. Via an idea incubated during her time at UNSW, she was transported from "student 
intern" to "international influencer", migrated after graduation to Hong Kong, a city epitomising corporate success. The advertisement's diptych provides a temporal and geographical narrative of Lily's educational metamorphosis into a "global", one of the mobile elite who dominate the upper echelons of transnational capitalism (Elliott and Urry 2010: 67). The fact she is seen from behind, which anonymises her, means that she could be anyone; anyone that is, with the propensity to "ask why not", a necessary credential for achieving "great things". Through all then, is the key idea of UNSW as an institution with the capacity to confer special powers, those of business acumen and globalism, powers that have transnational cogency and will literally, as well as socially, mobilise students; taking them places that will transform their futures.

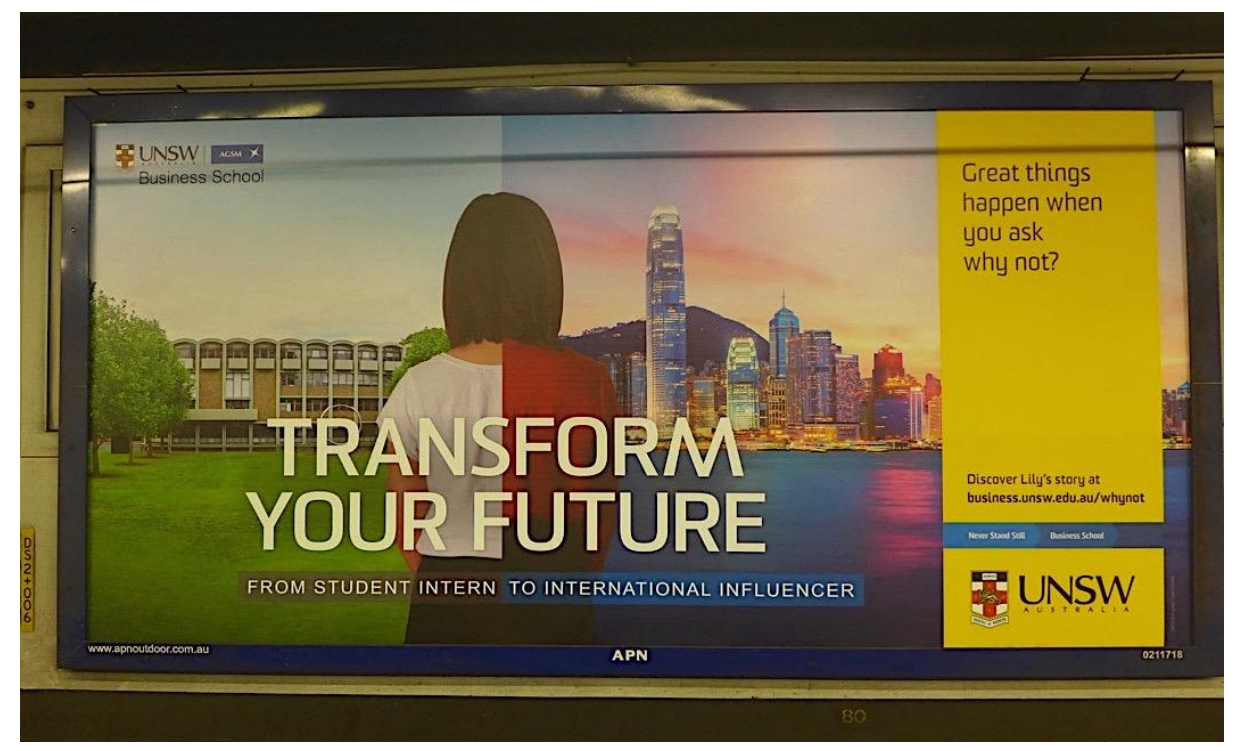

Figure 1 One example from UNSW "transform your future" series, which also includes two other stories from alumni who have transformed their future and our working in a global context.

Other advertisements emanating from UNSW also reveal how it is endeavouring to position itself as a global player on the higher education stage; that the university itself is going places, and that the viewer should hop aboard. Its "changemaker" series, one set of which was mounted outside Sydney Airport, portray the university as seminal in the development of the bionic eye, of a water purification system and so on. Its location is emblematic of its target audience, those cosmopolitan would-be students driving down airport drive, with fresh global mind-sets inspired by journeys abroad. By contrast, WSU's billboards hug the commuter arteries of western Sydney - typically, the M4 motorway, in flamboyant attempts to arrest the attentions of passing youth on their way from high school to supermarket, tutoring centre to sporting field. WSU, then, is happy to underline its 'western- 
ness', its role as an important provider of higher education to communities on Sydney's margins - nowhere better epitomised than in its new logo, a red ' $W$ ' inside a shield, with the word 'university', in a far less conspicuous grey, below the red 'Western Sydney'. It is illustrative of the position-taking that now pervades higher education, as universities seek to define themselves as local, national or global organisations (Marginson 2007: 32).

Passengers using Sydney's CBD stations might also observe the advertisements of other universities, or at least those with the requisite heritage, who promote their histories, as if they are not simply going places, but have already been places. They have a pedigree of moving people, and indeed, entire cities, nations and states. This is the case with a folio of advertisements utilising the telling slogan "leadership for good" issued by University of Sydney in 2015. The slogan is a good example of the type of double-speak employed in advertisements, where putting across "two messages for the price of one" not only makes economic sense (Redfern 1984: 130) but it also arouses the attention of those endeavouring to decode them. For the slogan suggests at one and the same time that the leadership capacities acquired at Sydney not only progressed society's happiness quotient but also had robust, generative powers. In providing vignettes of high-profile graduates, including a Prime Minister (Figure 2), a High Court judge, a feminist author and a cardiologist, the advertisements are 'individualised'. In so doing, they give endorsement to the fact that Sydney helped spearhead their commitment to social justice, multiculturalism and equal opportunity, thereby helping to make inclusion a cornerstone value of Australian society. In

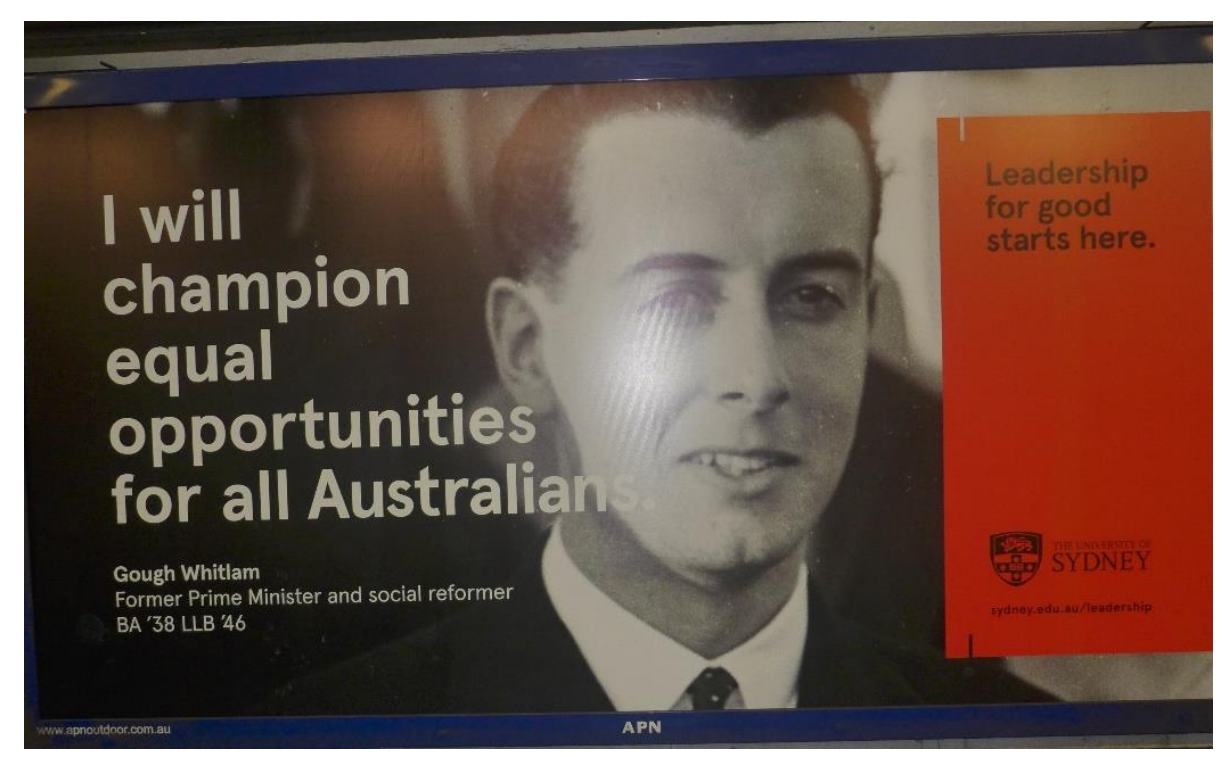

Figure 2 An advertisement from University of Sydney's Leadership for Good series that feature some aptly chosen words from national leaders along with a black and white portrait of them, taken during their time at the university. 
instilling in its students "learning for good", the University of Sydney, also helped transform our futures. For Gough Whitlam as Prime Minister was a "social reformer", who championed in his words "equal opportunities for all Australians". His photograph in the advertisement, in black and white, shows an intellectual and political leader, when his views on equality were still in embryo, were still being forged in the university's cloisters, during the 1930s and 1940s. This helps reify the university's importance in Australia's social, political and cultural history, as a provider of "learning for good". It thereby acts as a riposte to the implications alluded to in other university advertising that heritage universities are anachronisms, have lost touch with the zeitgeist. Unusually, in a climate where university discourses have become captive to ultra-instrumentalism, of learning as a private good, the University of Sydney brands itself as an institution where knowledge for a common good still prevails (Palmer 2015: 121). The message is clear: any passing commuter harbouring leadership ambitions should look to Sydney as their university of choice and should commence their engagement with the institution by following the URL in the bottom left-hand corner, which aptly reinforces leadership in its title.

In implicit criticism of these higher education advertisements that focus as it were, on the high calibre of alumni to project institutional prestige and market advantage (Favaloro 2015), 'newer' universities often impugn their sandstone rivals for not nimbly moving with a changing educational landscape, for being sessile, not directly but through marshalling the contrasting effects of loaded vocabulary. For example, Macquarie University has positioned itself as "not your traditional university", as if being traditional is an educational liability, a sign of fixity, of being pedagogically outdated, of not providing "learning for good". Its Pioneering Minds series looks conspicuously down the tracks, to forging the future and producing the new intellectual centurions, forward-looking leaders and advanced entrepreneurs who will impel society to move. Accordingly, Macquarie's future tense pedagogy encompasses opportunities for "learning outside the lecture theatre"- that ultimate bastion of educational anachronism - and working with "our global partners...first hand". Graduates will possess a "competitive edge", meaning, though it is not stated as such, in a globalised labour market. Giving knowledge a more applied and instrumental focus is the very obverse in other words of that 'advertised' at Sydney. As Australia's oldest and most traditional university, Sydney enthusiastically promotes its "signs of venerability" (Marginson 2007: 45). It is a reminder that venerable universities enjoy a positional advantage that cannot easily be usurped in the higher education field (Favaloro 2015: 499; Temple 2006: 17) and which no amount of inventive marketing or upselling of an evolved 
practice-focussed educational model can orchestrate. Moreover, feeder institutions like secondary schools are happy to prize this advantage. ${ }^{7}$ Sydney's possession of such assets as national leaders, neo-gothic architecture, a city campus and being Australia's first university (Gaztambide-Fernandez 2009), are ones of inestimable value and symbolise an institution able to withstand marketplace vagaries. ${ }^{8}$

By the same token, Macquarie is not interested in enrolling traditional students to affect its competitive edge, but only ones with so-called "pioneering minds" - minds that can look down the tracks, and indeed around the bend. Those sans such minds, presumably, need not apply! Such massaged rhetoric puts Macquarie's modernising billboards at loggerheads with Sydney's traditionalising ones. It is telling therefore that both sets of advertisements appeared on Sydney's Town Hall station where their narratives could easily be compared by those so-called 'hard to reach' would-be millennial students emerging from trains on all four of its intersecting lines that stretch to the north shore, the wealthy eastern suburbs, southern Illawarra, and out to Sydney's sprawling suburban west.

Seeking to take semiotic advantage of its new home in a Frank Gehry designed building, the University of Technology, Sydney (UTS), goes even further and intimates that the students attending its Business School will graduate with a "different school of thought", different that is, from its competitors (Figure 3). The building of Gehry, one of the architects most associated with the global iconomy (Smith 2006), represents an architectural emblem of this new style of cognition, the type of blue sky thinking implied in the background. Further, the building itself acts as an urban advertisement, projecting an image of boldness, creativity and difference, in an environment of architectural conformity. The curvature of its lines defies logic and insists on being seen precisely for "looking ... different", an icon of the much vaunted divergent thinking. Post-graduate students looking to acquire this thinking, are encouraged to attend the School's "Info Sessions", that is, if they want the opportunity to study in Gehry's thought conferring spaces.

\footnotetext{
${ }^{7}$ A newsletter from a high school located in one of the city's most diverse suburbs, identified those of its students who gained places at Sydney by name, an honour not extended to those winning places at other universities. In effect, there are losers among the winners. We are grateful to Susan Markose for this observation.

${ }^{8}$ The University of Sydney used its main neo-gothic building as a focal point of an advertisement inviting successful ATAR students to join them at Info Day ("Campus Tertiary Guide”, The Sydney Morning Herald, 11 December, 2015, 4).
} 


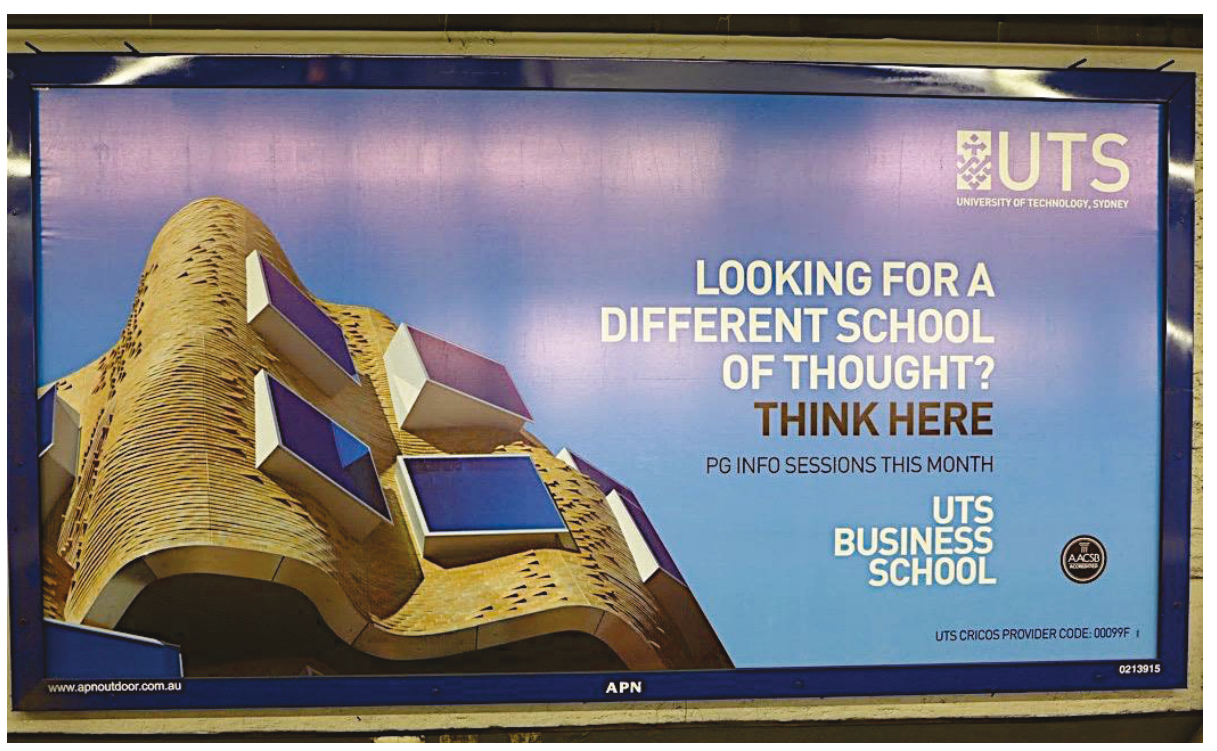

Figure 3 This advertisement shows one corner of the Gehry Building, in which UTS's School of Business is accommodated. Just visible is the fact that the School has the AASCB's (The Associate to Advance Collegiate Schools of Business) seal of approval.

Courting the idea of flexible pathways, another way of journeying through the tertiary education gauntlet, is one that the mainstream universities have inherited from the so-called "niche providers" (Palmer 2014: 138), that growing phalanx of small, independent private colleges, the para-academies that have effloresced in the wake of the Abbott government's decision to support them. ${ }^{9}$ Rather than the remit of programmes found in "your traditional university", they offer a different journey through programmes in such creative industries as animation, games and digital media. Hence, they are aimed at young people wanting, as the SAE Creative Media Institute indicates, on one of its billboards, a "life in Pixels". As the para-academies involved do not enjoy the same visibility and status as their state rivals, they are forced to advertise. However, rather than claiming to be the equal of mainstream universities, they claim the opposite, that their learning approaches complement those of the digital generation. As part of these attempts at institutional differentiation, they amplify their pedagogic versatility and relevance, position themselves as being on a path that is the opposite of the public universities, which are portrayed as stranded in the Gutenberg era, as having but tangential relevance to the digitals. An advertisement for Sydney's JMC Academy is not atypical: alongside the words "Your creative future starts today", a young woman is

\footnotetext{
${ }^{9}$ Given that questionability of the financial ethics of some of these providers, particularly in the vocational sector, this appears to have been foolhardy decision. Mercifully, another proposal from the same government, which would have seen the cap on university fees raised, in effect introducing a new numerus clausus, one with an economic rather than meritocratic basis, remains stalled in the Senate.
} 
shown singing into a microphone. She is adjacent to a mixing desk, a camera and a robotemblems of the "creative future", of the technology used to perform, record, animate and design, areas that JMC offers specialist diplomas, certificates and degrees. There is an urgency expressed in the injunctions on the advertisement's left "Your Creative Future Starts Today" and on its right "Enrol Now", implying 'don't wait'-be on the move. For much of the advertising of the para-academies focuses on identifying the putative failings of the real academies, one of which, as in this instance, is that enrolment is only permissible once or twice a year. Other advertisements from para-academies claim that they provide small classes, individualised pedagogy and opportunities to apply theory in practical contexts. These are qualities, so it is intimated, that are absent from government universities; that their classes are large, impersonal, lack real-world perspectives and are taught by academics lacking cogent industrial experience.

One of the most regular exponents of this view is the Australian College of Applied Psychology (ACAP). The fact that it is an "applied" college is indicative of its diehard instrumentalism. It embraces a similar model to those we have seen of public academies, by using the 'voice' of current and former students to expound their view, albeit a view that regular universities are outmoded (Figure 4). As a regular advertiser on Sydney's stations, ACAP is a prominent player in the frantic scramble to catch the attention of would-be

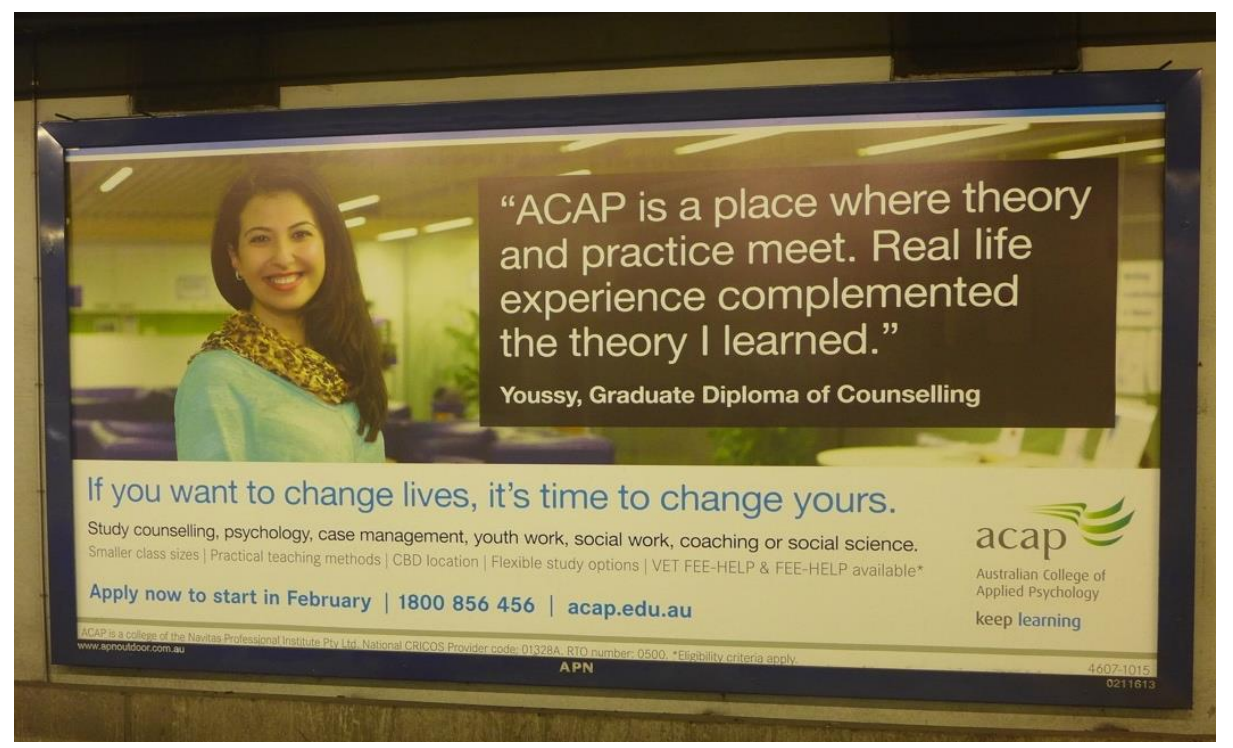

Figure 4 One of a series of ACAP advertisements, using former or current students to endorse its programmes. Note also, the logo above 'acap' in the bottom right hand corner, which signifies that ACAP is a member of the Navitas Group, to which a number of government universities also belong, e.g. Macquarie and Western Sydney.

students who frequent transit corridors and who might be disillusioned with the regular 
university. In the skirmish between private and public then, a version of the rhetorical tactics adopted by mainstream universities to prosecute their own pedagogic supremacy, is used by the para-academies to inveigh against their government rivals. It is a reminder that advertising discourses are adversarial in intent, are aimed at subverting their rivals' claims.

\section{Moving on track}

Though the university advertisements that have been analysed thus far are located in transport spaces, and can implicitly encourage readers to see study at their particular institutions as a form of journeying, as a mode of getting places, they do not explicitly engage with their transport sites. They could equally appear, as they often do, in newspapers and on the web, albeit in a scaled-down versions, without losing much of their iconic power or resonance. Indeed, until 2015, when the policy was modified, commercial advertising was prohibited on Sydney trains. It is now common to see advertising, both on the outsides and insides of trains, from a range of sources, including higher education and which utilise architectural paronomasia for its eye catching and humouring effects. In early 2016, UTS's latest advertisements (one already discussed) appeared on the outside of some carriages, thus giving them more reach and range than they had in their stationary versions, on city platforms. Indeed, when one of these, that for its Doctor of Juris programme, was transferred to a carriage, much of its trompe l'oeil impact was lost, that it was designed to look as though it was built into the built environment of a railway tunnel, and that someone had applied postit's to its walls. However, they do not really, as some higher education advertisements do (e.g. UTS's), relate to the railway context, other than in the very elliptical sense of education constituting a transporting experience. ${ }^{10}$ However, there are many that do, that play on education's 'destinational' effects. For example, a set from Charles Sturt University asks "We are curious to know where you are heading? Are you?"- the implication being that 'you' might be lacking direction, without goals - also seen as a deficiency in a society where being mobile is valued. Another, from UNSW, implies that its degrees are for those who "never stand still" - a clear assertion of the co-dependency of social and educational mobility, that being on the move and studying are mutually inclusive. That the UNSW advertisements are embedded in a framework of lines, assists to modulate the advertisement into its context and serves to normalize mobility as a predicate of success, that studying is

${ }^{10}$ Nor is such solely the province of educational institutions. A recent advertisement seen on a Sydney station suggests that if "Commutes are eating into your cooking time", then "We've got a soup for that". 
part of getting on in life, of going places. Education is after all, only another form of movement - one that takes place over time and in a range of spaces. In effect, doing a degree and one after that, are elements of the 'not standing still' philosophy, of avoiding being sessile. Another advertisement, from the APM College of Business and Communication, a private provider, actually consists of a railway map, translated into an educational timetable — one showing various 'stations' of a degree programme. It insinuates that APM degrees can be completed with more celerity than those from public universities. Hence, it provides a rationale for going private. It 'sets out' to appeal to those students who are not just on the move, but in a hurry, who are not in other words slow on the uptake, who are seeking a less than tardigrade transporting experience.

Other advertisements take a less abstract route to communicating their message. That from one of NSW's regional universities, Newcastle (UON), which 'figures' on some of Sydney's trains, incorporates the 'moving experience' into its narrative (Figure 5). It resorts to a railway image to marshal interest in UON as a possible place of study, in this instance, its Graduate School. Modulated into its railway context, the advertisement has situational specificity. Its shows a casually-dressed young woman, coffee in hand, waiting for her train. That she is in front of an amorphous mass of other "vehicular units" (Goffman 1971: 7), also waiting for their train, helps to 'distinguish' her. A commuter, viewing the advertisement will

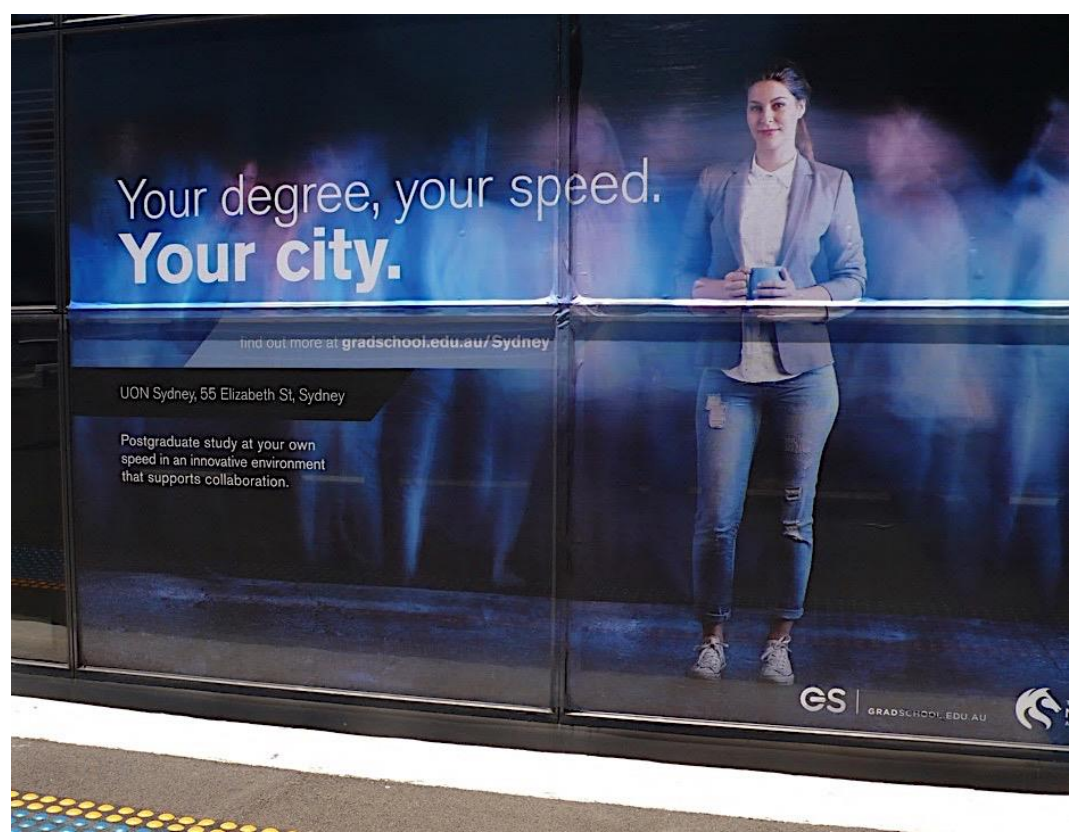

Figure 5 UON advertisement affixed to the side of a Sydney train, and which unusually, presumably because of its positional advantaging effects, gives the address of its city campus.

see themselves reflected, both literally and metaphorically, in the advertisement. The use of 
second person in the copy ("Your degree, your speed, YOUR CITY"), which is ubiquitous in university advertising, implies that other institutions do not provide Newcastle's degree of autonomy, that students cannot undertake the degree they want to, that it must be undertaken at a prescribed tempo and on its campus. They must be part of the crowd in other words, the blur. By contrast, at UON students do their own degrees, in their own time, and all, lest any of them think they have to travel 160 kilometres north of Sydney to the city of Newcastle to do so, can complete their degree locally, for UON has a campus, in Sydney's CBD, a few blocks from Wynyard Station — where a number of other universities have also sited their Sydney campuses. La Trobe, an interstate university, indicates in one of its Wynyard advertisements, that its degrees are "closer than you think", in fact, they are right above the station! It is a matter then, of the university coming to them and not the other way about.

Here, as elsewhere, deference to student need is writ large, that their education will come to them, that its temporal demands will be adjusted to suit their cognitive style and so on. UWSOnline, prior to its rebranding, advertised its degrees on billboards close to Sydney airport, and suggested that they offered "the best of both worlds", insinuating that travellers could take their studies in their suitcases. Such personalising of higher education is the forte, so it is suggested in its advertisements, of Open Universities Australia (OUA), a distance education provider, and 'seen getting around' on Sydney buses, in the opening months of 2016, at the height of the enrolment season. Under the strapline, "there is more than one way to learn", it is asserted that OUA, unlike its rivals of course, tailors its courses to suit the "study style" of its students, be they, as the advertisements 'portray' them, a "night owl", a "stickler" or a "crammer". Not surprisingly, OUA's tag is "uni on your terms" (even the language is your language) and reflects how much the post-Dawkins' university has deferred to the student, that the language of 'your university', as opposed to just plain 'university' predominates in advertising. Further, in a context when numerus clausus is applied elastically, it comes as no surprise that universities now offer would-be students 'special deals'. As UTS boasted in one of its advertisement, these have included reduced ATAR cutoffs for Bankstown residents ("You could be ten points closer to your degree").

The UON advertisement also highlights how important and propitious campuses that are located on railway stations have become. Witness the discontent expressed by Sydney, a campus with a plethora of public transport options, when its bid to have a station located on campus, on the soon-to-be-constructed, Bankstown metro-line, was rejected in favour of one at nearby Waterloo. This follows a parallel decision made in 2002 to re-route the Macquarie line, and which when it was planned, was to have a station serving UTS' Lindfield campus. 
Arguably, the re-routing, in large measure spearheaded by disgruntled locals who were opposed to a railway line in their gardens, led to the campus' eventual closure and its redevelopment as a residential site. ${ }^{11}$ By contrast, Macquarie University, situated on the rerouted line, regularly makes reference in its advertisements to the fact that its campus is rail accessible. One such advertisement canvasses a similar scenario to that of UON, a young woman waiting, who is shown in the throes of an epiphany, to the effect, that the imminent train might afford her an "extraordinary opportunity", that of studying for a post-graduate degree. The message is clear: do not miss the train; come on board, study for a post-graduate degree and thereby "Transform your career". An earlier advertisement from the same institution, also promoting its post-graduate degrees, asked its addressees "if they felt like a million dollars?" (probably not, as they were waiting for a train). In answering that question it was indicated that recipients of its post-graduate degrees earn 53\% more in their first year, which over a lifetime career adds up to "over a million dollars" - the ultimate private good (Figure 6). Just to further gild the lily of pecuniary instrumentalism, the advertisement also alluded to the university's other positional advantages: first, its proximity to the Macquarie Line (of which more in a moment); second, its proximity to a number of global, transnational corporations (mainly pharmaceutical and information technology ones) with which it has links. As was noted earlier, the "CBD worker", one disgruntled with their employment prospects, perhaps thinking about post-graduate study as a way to access a new career path, is one of APN's target markets. It is here the advertisement's "apply your mind" theme kicks in. Macquarie degrees are tailored to the needs of industry and business. Their holders possess credentials giving them automatic ingress into a global industry - though not presumably if it is in the arts or the humanities, for there are no creative industries in Macquarie's Silicon Gully. Indeed, it is what is absent from the advertisement's vignette of post-graduate study that is telling: there is no mention of traditional research or opportunities to study alongside leading edge scholars, no mention of the humanities, social sciences, arts or education, presumably because their pecuniary dividends are of a lesser order than those of business and industry. What is mentioned instead is a "train station", not any station but "our own station" (the use of the possessive is again telling) and "flexible study options" and which include being able to study on the train, and to work, no less, for "your salary increase on the way home". In other words, it gives real meaning to training. Further, in a clear instance of neoliberalised organisations now seizing every available opportunity for revenue capture,

${ }^{11}$ Not entirely though: some of the campus will be used for a high-tech high school. 
SydneyTrains in one of its leaflets reminds students that by using its then newly introduced Opal Card, they can "save $\$ 3.40$ each week between Macquarie University and Central" and which amounts over a lifetime to...... ${ }^{12}$

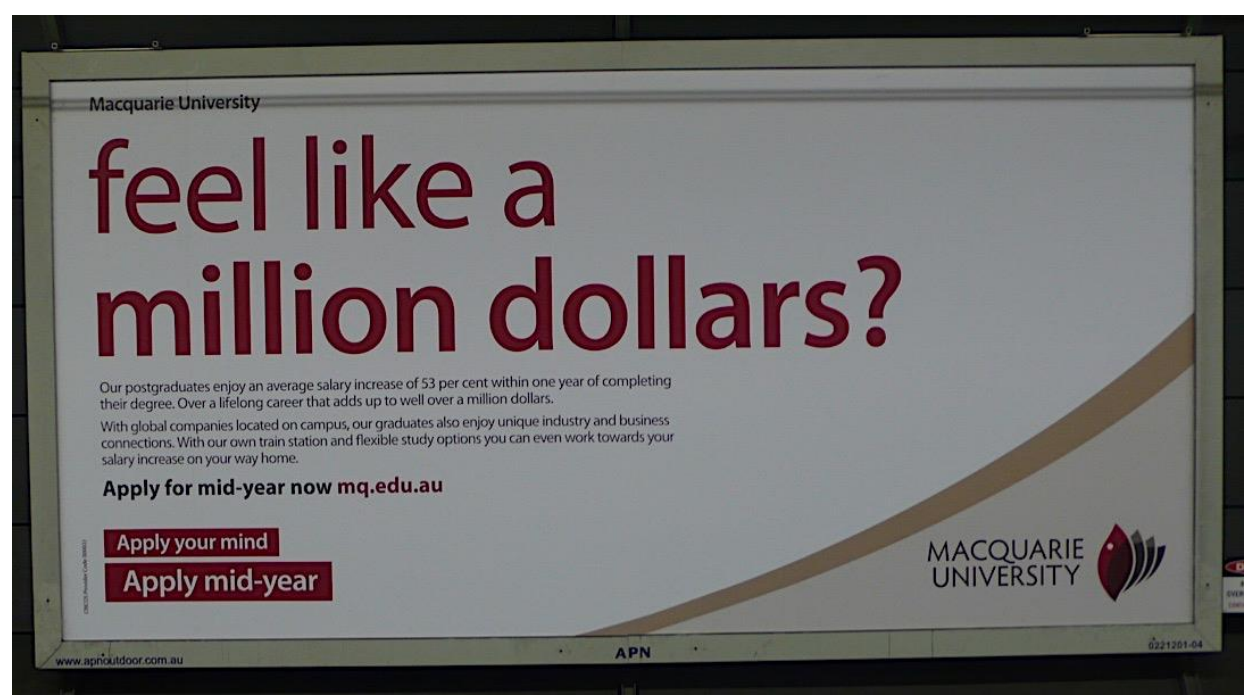

Figure 6 Macquarie University's portrayal of study as a pecuniary good.

\section{Conclusions}

Ironically then, advertisements for higher education in Sydney released over the last few years, along, in and around the city's commuter corridors, constitute something of a learning experience, yielding much that is enlightening about the current plight of universities as they struggle for market position, and compete for that increasingly valuable and hard to access commodity, students. For all the energy that marketing departments invest in outdoor commuter advertising, references to the pedagogic virtues of instrumentalism and pecuniary good are very pervasive. A textual ethnography of Australia's higher education iconomy as manifest in Sydney transport corridors reveals that universities, in contradistinction to their predecessors, are happy to promote the commercial and industrial cogency of their degrees. Invariably, the leitmotifs of being on the move, of going places are dominant ones in university advertising - one that is rendered all the more piquant in the context of transit environments, where people are actually on the move. For example, many institutions are happy promote to their credentials as business-oriented, to highlighting the idea of education as value-adding to existing credentials and thereby increasing an individual's employability (e.g. CSU's "Dream job out of your reach, then think again"). To this end, their courses are branded as ones which produce job readiness, lead to satisfying, transnational and 'enriching'

\footnotetext{
${ }^{12}$ See "Save with Opal" leaflet, issued in 2014.
} 
careers, meld theory and practice, are flexible and taught by industry leaders, and so on. Such advertisements reveal how careerist and vocational higher education now is, how the university is more like the College of Advanced Education than the university of yore, emphasising training goods at the expense of educational goods. In other words, they reveal how much the business of learning is tethered to business priorities, that universities are the learning arms of corporate capitalism.

This is not necessarily at behest of the universities themselves which have generally resisted this trend, but because of government fiat, requiring higher education institutions to direct their energies to meeting national goals and priorities. It is of note then that Bradley Review, but the latest of a series of inquiries charged with renovating Australia's higher education system, in emphasising social inclusion as a cornerstone value, did so primarily for economic reasons. To realise this goal, it replaced a supply-driven system by a demanddriven one, which placed the onus on students to determine whether a particular university met their capacities or not (Norton 2013). University advertising does not reveal ATAR cut off points, or what is required to undertake a university degree; instead, it focuses on such post-graduation benefits as employability and financial reward - information which can be acquired, incidentally, from more reliable sources such as the Federal Government's Quality Indicators for Learning and Teaching (QILT), a user friendly website detailing graduate outcomes and performance. Thus, the irony of a free market, whose architects espouse informed choice, is that advertising by its very nature, encourages decisions that are driven by down the track pecuniary ends. Further, even if university advertising was truly veracious, a combination of 'auditory' surveillance and graduate outcome frameworks that now straightjacket university pedagogy ensures that higher education is increasingly homogeneous and isomorphic (Marginson and Considine 2000: 176; Thornton and Shannon 2014: 161).

In spite of the concerted attempts to make institutions 'look' and 'be' different, the overall results, save the University of Sydney, which promotes its heritage credentials, insinuate institutional uniformity not diversity. It would therefore be reasonable to ask whether the funds expended on producing university iconomies, especially when it comes at the expense of economising teaching, is not misplaced? Surely, they should be deployed in providing students with the types of resilient and critical learning that could really take them, and their societies places, thereby putting higher education properly back on the rails.

\section{References}

Bagshaw, Eryk (2016) “The numbers game”, The Sydney Morning Herald, 30-31 January, 1, 
$23,26-7$.

Bauman, Z. (1988) Freedom. Milton Keynes: Open University Press.

Bourdieu, Pierre (1984) Distinction: a social critique of the judgement of taste. Cambridge, Mass: Harvard University Press.

Brown, Roger (2011) "The march of the market”, in Molesworth, Mike, Scullion, Richard and Nixon, Elizabeth (ed.) The marketisation of higher education and the student as consumer, 11-24. London: Routledge, 2011.

Cervini, Erica (2015) "Universities spend millions on marketing but word of mouth from students seems just as effective", The Sydney Morning Herald, 25 October.

Davies, Susan (1989) The Martin Committee and the binary policy of higher education in Australia. Melbourne: Ashwood House.

Dawkins, John (1988) Higher education: a policy statement. Canberra: AGPS.

Edensor, Tim (2003) "Defamiliarizing the mundane roadscape", Space and Culture, 6 (2): 151-168.

Elliott, Anthony and Urry, John (2010) Mobile lives. London: Routledge.

Favaloro, Chrissa (2015) “Marketing in the Australian higher education sector”, Journal of Higher Education Policy and Management, 37 (5): 490-506.

Gallagher, A. P. (1982) Coordinating Australian university development: a study of the Australian Universities Commission 1959-1970. St Lucia, Qld.: University of Queensland Press.

Gaztambide-Fernandez, R (2009) "What is an elite boarding school?", Review of Educational Research, 79 (3): 1090-1128

Genette, Gerard. Paratexts: thresholds of interpretation. Cambridge University Press, 1997.

Goffman, Erving (1971) Relations in public: microstudies of the public order, New York: Basic Books.

Gudis, Catherine (2004) Buyways: billboards, automobiles and the American landscape. New York: Routledge.

First Report of the Commonwealth Advisory Committee on Advanced Education (Murray Report), Canberra: Government Printer, 1966.

Haywood, Helen, Jenkins, Rebecca and Molesworth, Mike (2011) “A degree will make all your dreams come true: higher education as the management of consumer desires", in Molesworth, Mike, Scullion, Richard and Nixon, Elizabeth (ed.) The marketisation of higher education and the student as consumer, 183-195. London: Routledge, 2011.

Hil, Richard (2012) Whackademia: an insider's account of the troubled university. Sydney: 
NewSouth Publishing.

James R., Baldwin, G. and McInnis, C. (1999) Which university? The factors influencing the choices of prospective undergraduates. Canberra: Department of Employment, Education, Training and Youth Affairs.

Jaworksi, Adam and Thurlow, Crispin (2010) "Introducing semiotic landscapes", in Jaworksi, A. and Thulow, C. (ed.) Semiotic landscapes: language, image, space, 140. London Continuum.

Jensen, Ole B. (2009) "Flows of meaning, cultures of movements - urban mobility as meaningful everyday practice", Mobilities, 4 (1): 139-158.

_ (2014) Designing mobilities. Aalborg: University of Aalborg Press, 2014.

Kaufmann, Vincent (2002) Rethinking mobility: contemporary sociology. Aldershort: Ashgate.

Kemp, D and Norton, A. (2014) Review of the demand driven funding system. Canberra: Department of Education and Training.

Kimber, M. and Ehrich, C. (2015) “Are Australia's universities in deficit? A tale of generic managers, audit culture and casualization", Journal of Higher Education Policy and Management, 37 (1): 83-97.

Klopper, C and Power, B (2014) “The casual approach to teacher education: what Effect does casualisation have for Australian university teaching?", Australian Journal of Teacher Education, 39 (4): 101-114.

Mather J. (2013) "Group of Eight debates university entry level lift", The Australian Financial Review, 15 July, from http://www.afr.com/p/australia20/group_of_eight_debates_university_J3PbEfnmc3mkLDIRdRsazJ

Marginson, Simon (1997) Markets in education. St. Leonards, NSW: Allen and Unwin. (2007) "The new higher education landscape: public and private goods, in global/national/local settings", in Marginson, S. (ed.) Prospects of higher education: globalization, market competition, public goods and the future of the university, 2977. Rotterdam: Sense Publications.

Marginson, Simon and Considine, Mark (2000) The enterprise university: power, governance and reinvention in Australia. Cambridge: Cambridge University Press.

Metro-Roland, Michelle M. (2011) Tourists, signs and the city: the semiotics of culture in an urban landscape. Farnham: Ashgate.

Miller, Peter and Rose, Nikolas (1997) "Mobilizing the consumer: assembling the subject of consumption", in Miller, P and Rose, N (ed.), Governing the present, 114-141. 
Cambridge: Polity Press.

Moodie, Gavin (2011) “The developing student market in Australian higher education”, in

Brown, R. (ed.) Higher education and the market, 63-73. London: Routledge.

Norton, Andrew (2013) Keep the caps off! Student access and choice in higher education, Carlton, Vic: Grattan Institute.

Palmer, Nigel (2014) “The modern university and its transactions with students" in Thornton,

Margaret (ed.) Through a glass darkly: the social sciences look at the neo-liberal university, 121-139. Canberra, ACT: Australian National University Press.

Redfern, Walter (1984) Puns. Oxford: Basil Blackwell.

Report of the Committee on Australia universities (1957) "Murray Report", Canberra, ACT:

Government Printer.

Review of Australian higher education (2008) "Bradley Review", Canberra, ACT:

Department of Education, Employment and Workplace Relations.

Ross, Julian (2000) Railway stations: planning, design and management. Oxford: Architectural Press.

Smith, Terry (2006) The architecture of aftermath . Chicago: University of Chicago Press.

Symes, Colin (1996) “Selling futures: a new image for Australian universities?", Studies in Higher Education, 21 (2): 133-147.

_ (2007) “Coaching and training: an ethnography of student commuting on Sydney's suburban trains", Mobilities, 2 (3 ): 443-46.

Temple, Paul (2006) “Branding higher education: illusion or reality?” Perspectives: Policy and Practice in Higher Education, 10 (1): 15-19.

Thornton, Margaret and Shannon, Lucinda (2014) “'Selling the dream': law school branding and the illusion of choice", in Thornton, Margaret (ed.) Through a glass darkly: the social sciences look at the neo-liberal university, 157-178. Canberra, ACT: Australian National University Press.

Urry, John (2000a) Sociology beyond societies: mobilities for the twenty-first century. London: Routledge.

(2000b) "Mobile sociology”, British Journal of Sociology, 51 (1): 185-203. 